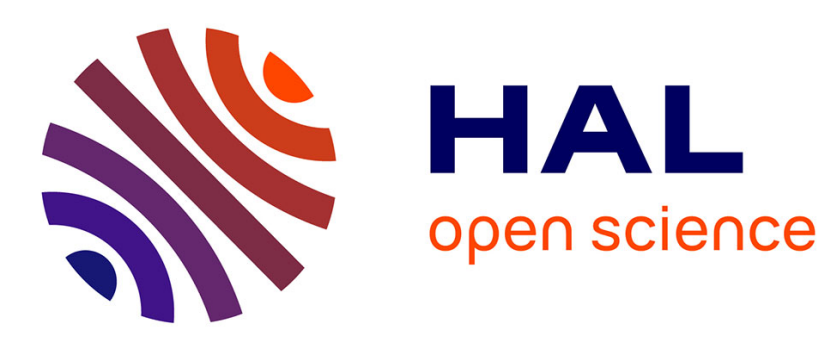

\title{
Does Something Change in the Oil Market with the Covid-19 Crisis?
}

Dan Zhang, Frédéric Lantz, Arash Farnoosh

\section{To cite this version:}

Dan Zhang, Frédéric Lantz, Arash Farnoosh. Does Something Change in the Oil Market with the Covid-19 Crisis ?: Cahiers de l'Economie, Série Recherche, n¹44. 2021. hal-03500719

\section{HAL Id: hal-03500719 https://hal-ifp.archives-ouvertes.fr/hal-03500719}

Preprint submitted on 22 Dec 2021

HAL is a multi-disciplinary open access archive for the deposit and dissemination of scientific research documents, whether they are published or not. The documents may come from teaching and research institutions in France or abroad, or from public or private research centers.
L'archive ouverte pluridisciplinaire HAL, est destinée au dépôt et à la diffusion de documents scientifiques de niveau recherche, publiés ou non, émanant des établissements d'enseignement et de recherche français ou étrangers, des laboratoires publics ou privés. 


\section{LES CAHIERS DE L'ÉCONOMIE}

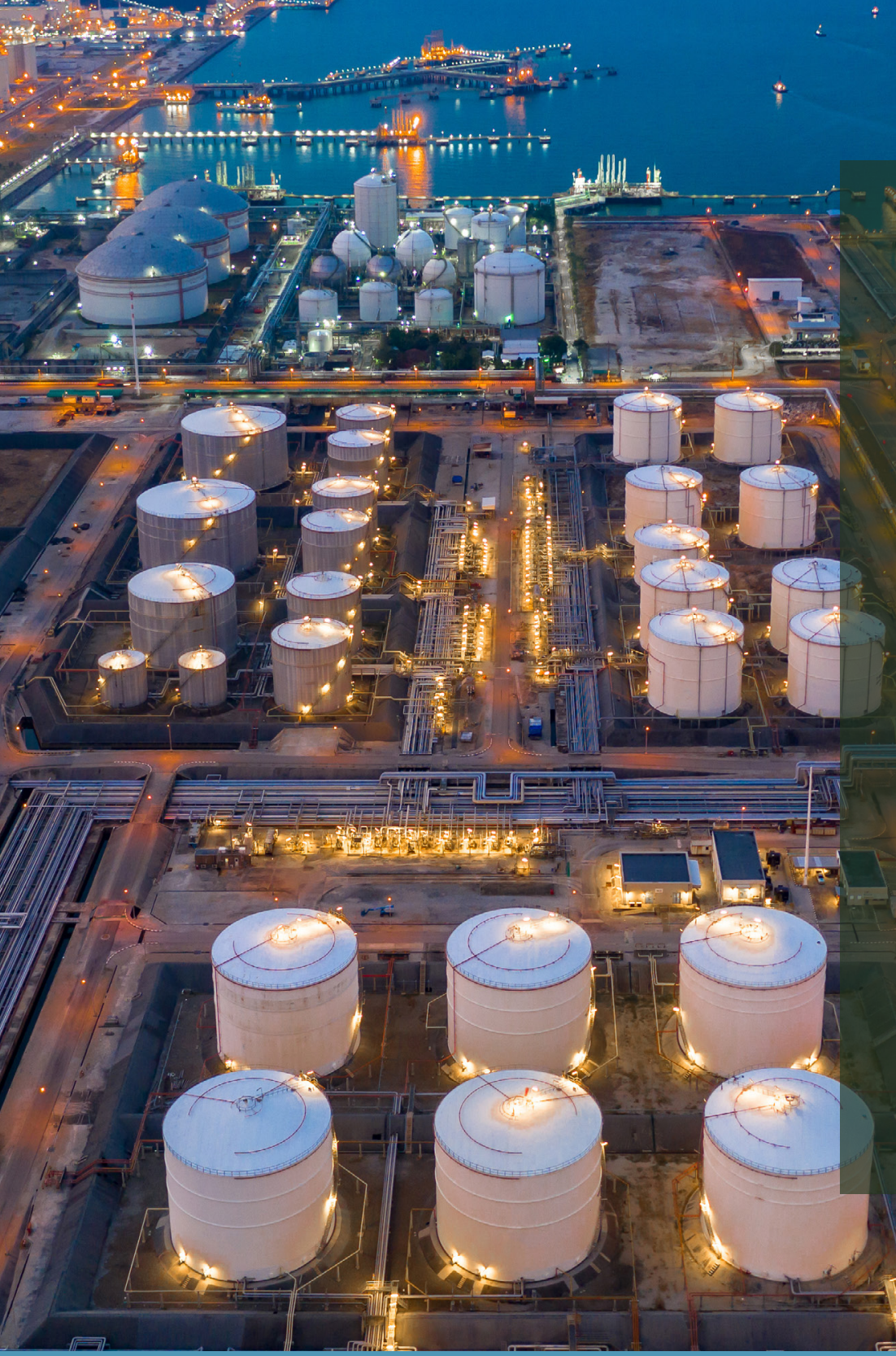

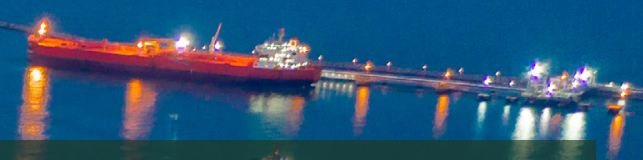

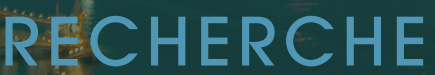

DOES SOMETHING CHANGE IN THE OIL MARKET WITH THE COVID-19 CRISIS?

This paper examines the price discovery of three international crude oil futures markets (WTI, Brent, INE) before and after the outbreak of the COVID-19 with the application of information share and component share model:

Dan Zhang Frédéric Lantz Arash Farnoosh

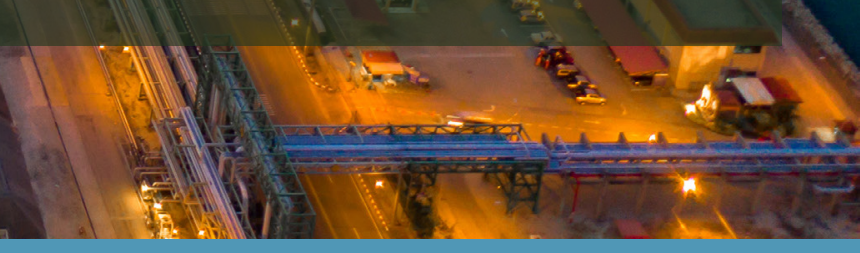


La collection "Les Cahiers de l'Économie" a pour objectif de présenter les travaux réalisés à IFP Energies nouvelles et IFP School qui traitent d'économie, de finance ou de gestion de la transition énergétique. La forme et le fond peuvent encore être provisoires, notamment pour susciter des échanges de points de vue sur les sujets abordés. Les opinions exprimées dans cette collection appartiennent à leurs auteurs et ne reflètent pas nécessairement le point de vue d'IFP Energies nouvelles ou d'IFP School. Ni ces institutions ni les auteurs n'acceptent une quelconque responsabilité pour les pertes ou dommages éventuellement subis suite à l'utilisation ou à la confiance accordée au contenu de ces publications.

Pour toute information sur le contenu, contacter directement l'auteur.

The collection "Les Cahiers de l'Économie" aims to present work carried out at IFP Energies nouvelles and IFP School dealing with economics, finance or energy transition management. The form and content may still be provisional, in particular to encourage an exchange of views on the subjects covered. The opinions expressed in this collection are those of the authors and do not necessarily reflect the views of IFP Energies nouvelles or IFP School. Neither these institutions nor the authors accept any liability for loss or damage incurred as a result of the use of or reliance on the content of these publications.

For any information on the content, please contact the author directly.

\title{
Pour toute information complémentaire For any additional information
}

\author{
Victor Court \\ IFP School \\ Centre Economie et Management de l'Energie \\ Energy Economics and Management Center \\ victor.court@ifpen.fr \\ Tél +33147527317
}




\title{
Does something change in the oil market with the COVID-19 crisis?
}

\author{
Dan Zhanga,b,*, Frédéric Lantz ${ }^{\text {b }}$, Arash Farnoosh ${ }^{b}$ \\ a China University of Petroleum (Beijing),18 Fuxue Road ,Changping Disrict ,102249 Beijing, China \\ b IFPEN, IFP School, 232 Avenue Napoléon Bonaparte, 92852 Rueil-Malmaison, France \\ *Corresponding author.
}

Emails: danzhang.424@gmail.com (Dan zhang); Frederic.lantz@ ifpen.fr (Frédéric Lantz); arash.farnoosh@ifpen.fr (Arash Farnoosh);

\begin{abstract}
:
This paper examines the price discovery of three international crude oil futures markets (WTI, Brent, INE) before and after the outbreak of the COVID-19 with the application of information share and component share model. Our study shows that there is a structural break of the date of $6^{\text {th }}$ of March,2020 in each price series with Zivot and Andrew's unit root test. Using Gregory and Hansen cointegration tests, cointegration relationships with structural break in May,2020 are detected. According to results of IS and CS model of Yan and Zviot (2010), Brent futures price mainly plays a leading role of WTI and INE futures price and occupies an absolute dominant position all the time in the three crude oil futures markets systems. In the post-covid period, the price discovery efficiency of INE has been improved slightly but is still weak compared with other two markets. After the outbreak of COVID-19, the dominant position in price contribution in the relationship with INE has transferred from Brent to WTI. These findings offer practical implications for regulators and portfolio risk managers during the unprecedented uncertainty period provoked by the COVID-19 pandemic.
\end{abstract}

Keywords: Oil Market, Price discovery, Structural Break

JEL Code: C32, C53, Q41 


\section{Introduction}

Shanghai Crude oil futures market, known as a new international crude oil futures market in China. Since 2018, it has experienced an increasing number of trading volume which even exceeded Dubai to become the third crude oil futures market in the world. Specially, world oil demand fell sharply because of the COVID-19 in 2020. Thus, crude oil prices fluctuated drastically during this period from the 2019-2021. On April $20^{\text {th }}$, 2021, US oil benchmark West Texas Intermediate (WTI) fell to negative for the first time. Meanwhile, China's outbreak was considered under control and its economy began to recover due to the government strict confinement policy while the confirmed cases of Europe still went up and crude oil demand remains depressed. Based on the existing facts, we suppose that these market changes have a significant impact on crude oil price fluctuations and the relationships between different oil markets and we also wonder what changes has happened in oil markets from 2019 to 2021.

In fact, many previous studies have shown that epidemics, geopolitical conflicts, natural disasters, and other exogenous events have a significant impact on economic variables(Nippani * \& Washer, 2004; L. Wang \& Kutan, 2013). Major part of the recent studies investigate the economic impact of government policy interventions (Alexakis, Eleftheriou, \& Patsoulis, 2021; Zaremba, Aharon, Demir, Kizys, \& Zawadka, 2021). For example, Ashraf (2020) found that government announcements regarding public awareness programs, testing and quarantining policies, and income support packages largely result in positive market returns. Many researchers and experts are focusing on stock market to explore the spillovers volatility and co-movements between different countries' stock markets or between stock market and many other financial markets (Abuzayed, Bouri, Al-Fayoumi, \& Jalkh, 2021; Ben Amar, Fateh, Youssef, Chiao, \& Guesmi, 2021). Alqahtani, Selmi, and Hongbing (2021) reveal that the volatility transmission from oil market to G20 countries' stock market became more pronounced with the onslaught of the coronavirus pandemic. The results of Bakas and Triantafyllou (2020) show that the economic uncertainty of pandemics has a strong negative impact on the volatility of commodity prices, especially crude oil markets. For instance, Bourghelle, Jawadi, and Rozin (2021) analyze the dynamics of oil price volatility in the context of the COVID-19 and find pandemic shock affected oil price volatility significantly

Our paper is aimed to test whether there is a structural break in crude oil prices and explore the price discovery of international crude oil markets under the background of the COVID-19 by the methods of information share and component share. Our study contributes to the literature along several important dimensions. First, we add to a rapidly expanding body of literature exploring the financial implications of the COVID-19 pandemic especially in the field of crude oil markets. Second, by unit root test and cointegration test with structural break, a breakpoint in crude oil price series due to pandemic from 2019 to 2021 can be observed. It is helpful for us to make a deep exploration about the influence of exogenous shocks to price 
discovery process. Third, since the recent launch of Shanghai Crude oil futures, the comparative research between INE and other benchmark prices are still insufficient. In recent years, significant changes have taken place in the crude oil markets as we mentioned before. Our paper could enrich the literature on empirical analysis of three different crude oil futures markets. Apart from theoretical contributions, our findings offer practical implications for regulators, policymakers, and portfolio risk managers during the unprecedented uncertainty period provoked by the COVID-19 pandemic.

Overall, we firstly find that there is a breakpoint which is tested as $6^{\text {th }}$ March,2020 in WTI Brent and INE price time series. Take the cointegration relationships two by two, the structural break occurred on $12^{\text {th }}$ of May because the impact of negative WTI price in April. We apply the $6^{\text {th }}$ of March,2020 to divide the whole sample into two sub-samples (the precovid period and post-covid period). For the whole sample, both IS and CS results show that Brent futures market contributes more share than other two markets. Although information share and component share of INE market are smallest among these three markets, they increased slightly after the pandemic outbreak which means the price discovery efficiency has improved due to the COVID-19. Between the group WTI and Brent, Brent plays a dominant role in price discovery in the whole period but when it comes to subperiod (both pre-covid and post-covid period), the IS and CS of WTI surpass those of Brent.

The plan of the paper is as follows. Section 1 presents the economic context of the worldwide economic activity and the oil market in 2019-2021. Section 2 provides a description of the related studies in this domain. Section 3 introduces the empirical methodology and tests applied in this paper. In section 4, empirical results and interpretation are presented to show the changes in the price discovery of WTI Brent and INE futures market before and after the COVID-19 outbreak. Finally, we summarize the results in the conclusion and we give some policy implications

\section{Economic Context of the Oil Market in 2019-2021}

Since the wide spread of the COVID-19 pandemic all over the world, it has caused unprecedented effects of public health and safety, industrial production and economic activities. Due to new virus mutations and the accumulating human toll raise, global prospects are still highly uncertain even as growing vaccine coverage lifts sentiment. When it comes to the global economy, as Table.1 shows, Gross domestic product (GDP) fell by $-3.3 \%$ by 2020 according to the latest World Economic Outlook issued by IMF (International Monetary Fund). For most countries, except China in 2020, the GDP growth experienced a negative value affected by the pandemic and the whole world will enter into recovery in 2021.This situation aligns with the oil consumption. Most regions witness a considerable in oil consumption. In contrast, the figure of China increases slightly. Therefore, the after-effects of the COVID-19 has aroused wide concern among scholars. 
Table.1 World Economic Growth and Oil consumption

\begin{tabular}{|l|l|l|l|l|}
\hline & \multicolumn{3}{c}{ Real GDP } & Oil Consumption \\
\hline Countries and Regions & 2019 & 2020 & 2019 & 2020 \\
\hline World & 2.9 & -3.3 & 4422.68 & 4006.73 \\
\hline United States & 2.3 & -3.5 & 844.9 & 739.7 \\
\hline Euro Area & 1.2 & -6.6 & 700 & 603.1 \\
\hline China & 6.1 & 2.3 & 654.3 & 669.2 \\
\hline India & 4.2 & -8 & 236.5 & 231.1 \\
\hline ASEAN-5 & 4.8 & -3.4 & 206.1 & 224.7 \\
\hline Latin America and the Caribbean & 0.1 & -7 & 274.2 & 246.1 \\
\hline Middle East and Central Asia & 1.2 & -2.9 & 390.8 & 361.2 \\
\hline Saudi Arabia & 0.3 & -4.1 & 153.2 & 150 \\
\hline South Africa & 3.1 & -1.9 & 29.9 & 25.9 \\
\hline \multicolumn{1}{|c|}{ Source: Real-GDP(\%):World Economic } & Outlok issued by IMF(International Monetary Fund) \\
\hline
\end{tabular}

Oil consumption(Million tonnes): BP Statistics Review of all the energy 1965-2020

When it comes to crude oil markets, the crude oil futures market has changed a lot all over the world in recent years. On March 26, 2018, Chinese crude oil futures, the first international futures product from China, were officially listed on the Shanghai International Energy Exchange (INE). Shanghai crude oil futures market has developed rapidly since its launch, especially after the outbreak of the pandemic. In the first half of 2020, the average daily trading volume of crude oil futures in Shanghai was about 18 thousand lots, up 3\% and 286\% respectively from the same period last year. It replaced Dubai and became the third largest crude oil futures after WTI and Brent crude oil futures in terms of trading volume. On April 20, 2020, US oil benchmark West Texas Intermediate (WTI) fell from $\$ 17.85$ at the start of the trading day to negative $\$ 37.63$ by the close. Without any doubt that is the biggest black swan event in crude oil markets in 2020 after the pandemic outbreak. In other words, we can't help but wonder how these crude oil futures markets react to the COVID-19 crisis? Does something change in the oil market with the pandemic? Whether different crude oil markets behave differently with the arrival of new information?

So far, according to Shanghai International Energy Exchange, in total there are 120 thousand accounts opened in Shanghai crude oil futures market. In 2019, the trading volume of corporate clients in INE market increased from $23 \%$ to $35 \%$ and open interest of corporate 
clients increased from $47 \%$ to $63 \%$. Volume of overseas customers increased $106.5 \%$ year on year, the proportion increased from $7 \%$ to $15 \%$. The open interest of overseas customers increased $122.1 \%$ year on year and the proportion increased from $14 \%$ to $22 \%$. Trading volume and open interest data reflect a sharp rise in institutional and foreign investor engagement, which means the market is gradually maturing and becomes more independent. From figure.1, we can see the INE volumes picked up significantly especially in May and June when the WTI negative price event just happened in April. At the height of the demand collapse and the stress felt by several oil benchmarks, we can reasonably doubt that there is something changed in international oil markets before and after the COVID-19 outbreak. Intuitively, Figure 2 shows us that the trading volume between INE and WTI, Brent has decreased after 2020 which is arousing our interest in exploring the price discovery with a structural break in world oil markets.

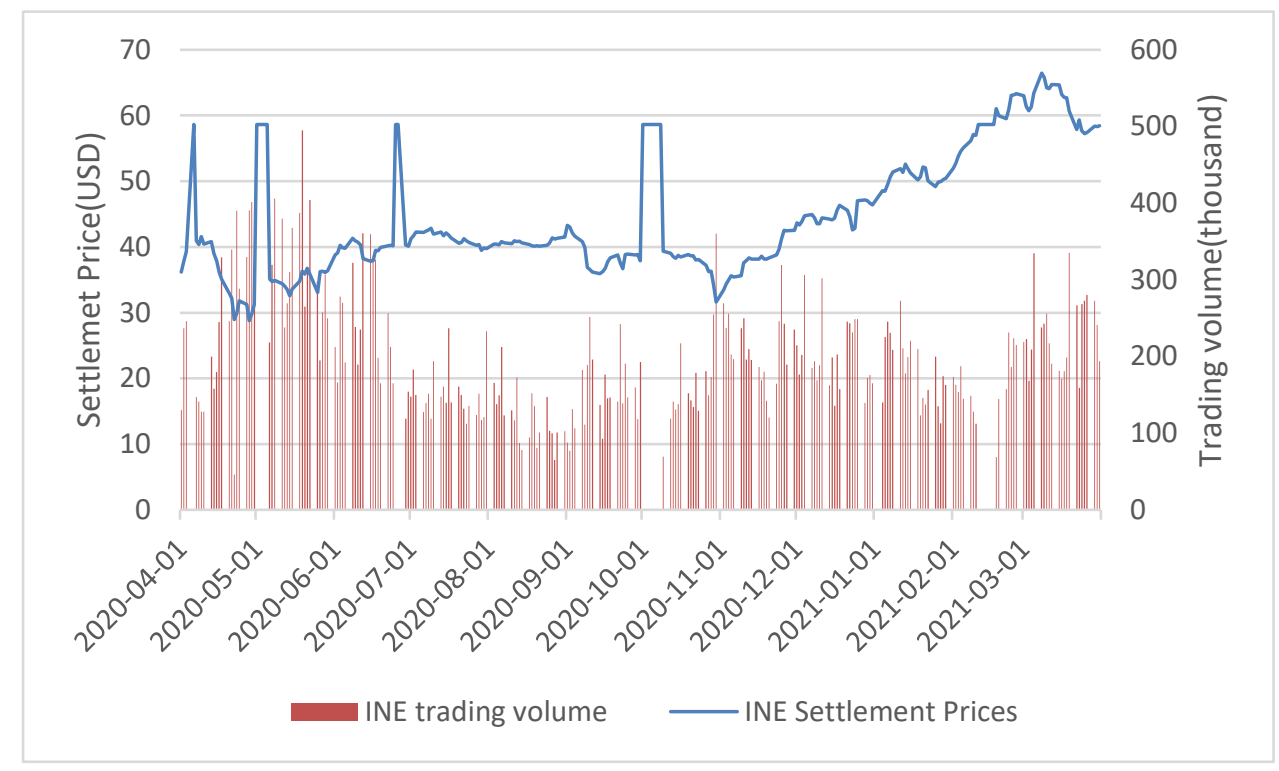

Figure 1. INE crude oil contract: settlement prices and volumes 


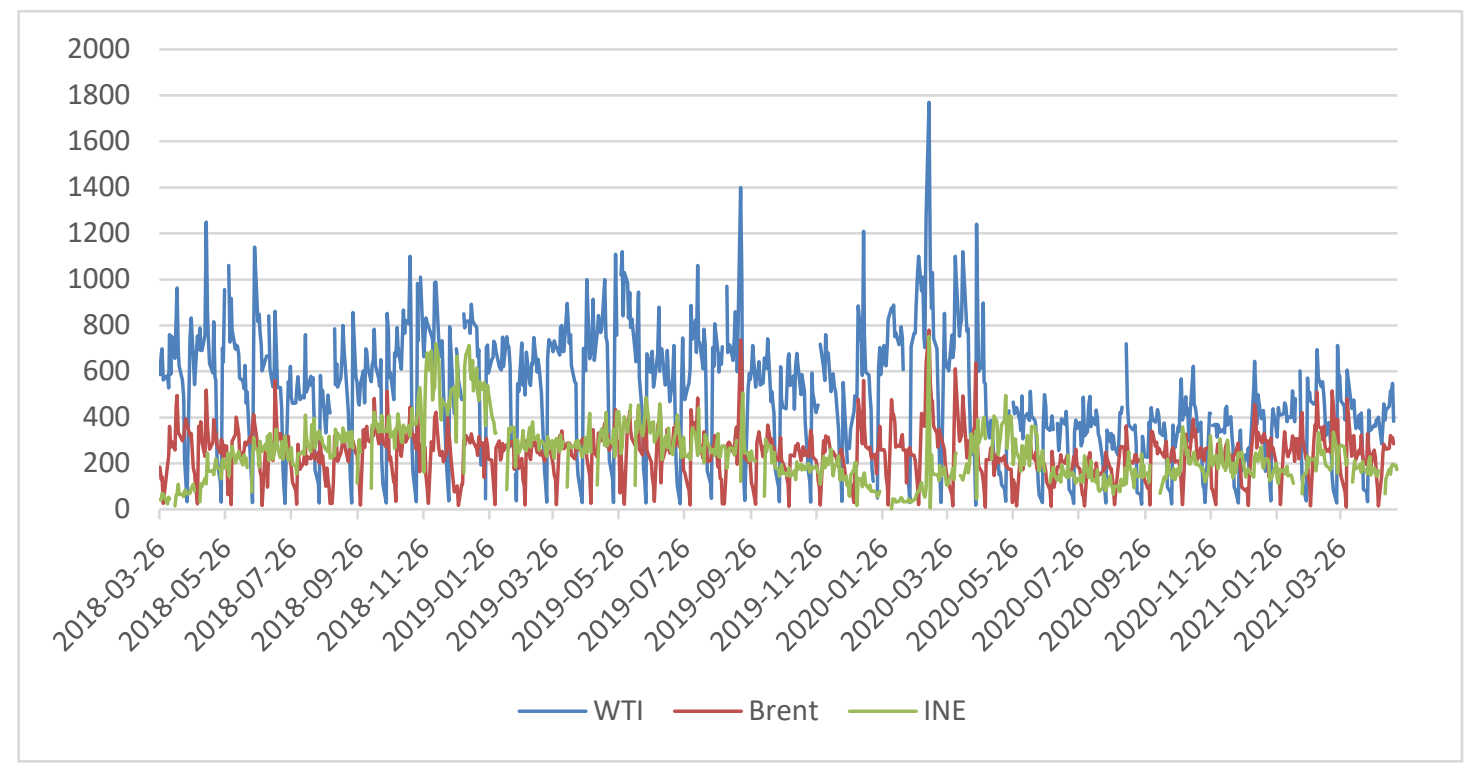

Figure 2. Trading volume (thousand) of WTI, Brent, INE

Source: CME group

\section{Review of Literature}

The essence of the price discovery is to explore which market product moves closer to the intrinsic value (Irwin, 1933). Garbade and Silber (1983) consider price discovery to reflect one of the major contributions of futures markets to the organization of economic activity. In the market microstructure literature, Schwarz and Szakmary (1994) interpret the price discovery as a process of searching for an equilibrium price. During this process, news and information implicit will be incorporated into market prices (Baillie, Booth, Tse, \& Zabotina, 2002; Lehmann, 2002). To sum up, price discovery is a market spontaneous behavior that market prices adjust fast from the old equilibrium to the new equilibrium with the arrival of new information.

In the field of international crude oil market, there is a significant body of literature to explore the price discovery futures market. The study of Schwarz and Szakmary (1994) strongly proved that futures dominate in price discovery in all three petroleum product markets: crude oil, heating oil and unleaded gasoline. Silvério and Szklo (2012) measure the contribution of the WTI futures market to the price discovery process in the spot market for benchmark crude oils, results show that the contribution of futures market grew over time because of the financial market impact. $\underline{Y}$. Wang and Wu (2013) reveal that the leadership between crude oil spot and futures prices is different at different time scales by multi-frequency analysis. There exists an alternate lead-lag structure instead of a dominance between the futures and spot market in the case of WTI (Shao, Yang, Shao, \& Stanley, 2019).

The above studies all focus on the price discovery of futures market and spot market, actually price discovery process also exists between different futures markets. Elder, Miao, and 
Ramchander (2014) compare the two benchmark oil price WTI and Brent, finding that WTI maintains a dominant role in price discovery relative to Brent, with an estimated information share in excess of $80 \%$, over a sample from 2007 to 2012. As the results of Hammoudeh, Ewing, and Thompson (2008) show that the impact of supply and demand shocks on one region quickly affects other regional markets when they prove the evidence of cointegration in four oil benchmark prices (WTI, Brent, Dubai and Maya).There is no doubt that the COVID-19 pandemic brings huge supply and demand shocks to the whole crude oil markets. Hence, it's safely to induce that the price discovery mechanics will change between the first three international crude oil futures markets (WTI, Brent, INE) because of the COVID19.There are also some studies focusing on these three markets. Yang and Zhou (2020) have analyzed at 5-minute intervals the first three months of the INE oil futures trading to document evidence of cointegration relationships among the Chinese INE futures and the Brent, WTI and Oman futures markets. Palao, Pardo, and Roig (2020) use multiple regression models to study the impact of the new Chinese oil futures contract compared with the WTI and Brent for an analysis period from March 26, 2018 to June 5, 2020 .They find that INE futures contract still plays a minor role on the market at a worldwide level.

From previous literatures, many methods can be used to measure price discovery between markets. For instance, Bentzen (2007) use an error correction model approach of Engle and Granger (1987) to compare several different crude oils - WTI, Brent, Alaska North Slope, Dubai Fateh, and the Indonesian Arun and find that there is a tight link between the world oil markets. Wlazlowski, Hagstromer, and Giulietti (2011) apply Granger causality tests to study the price dependence of 32 crudes in order to establish which crudes drive other prices and which ones simply follow general market trends. Apart from the error correction model and Granger causality tests, there are two popular common factor models that are used to investigate the mechanics of price discovery: Information share (Hasbrouck, 1995) and Component Share (Gonzalo \& Granger, 1995). Both are used to directly measure the contributions to market implicit value. IS model measures each market's relative contribution to innovations variance while CS model measures each market's contribution to the common factor, where the contribution is defined to be a function of the markets' error correction coefficients. In our study, we take both IS and CS method to compare the price discovery before and after the COVID-19 for the sake of robustness of the results.

\section{Methodology and Tests}

The data employed in this study to explore price discovery in oil market consist of daily log closing prices of the WTI, Brent, INE futures. INE crude oil futures is quoted in RMB, so we need to adjust the price by the USD-RMB exchange rate so that its price would be on par with the WTI and BRENT. The samples are over the period from March 26th, 2018 to March 31st, 2021. For the negative price of WTI on April 20, 2020, we replace it by a moving average before applying the logically approach. Intuitively, we can observe the characteristics of log 
price of three international crude oil price from Figure 3. An observable linkage between these three time series is shown, and the degree of deviation between these series has gradually decreased since the launch of the INE crude oil futures in 2018. In the first half year of 2020 when COVID-19 spread across the whole world, the logarithmic price fluctuates obviously and then the deviation degree of the three is magnified to a certain extent. A drastic fluctuation can be observed from March to June 2020. During this period, WTI price went negative at close and bring a huge panic to the crude oil markets. From this time onwards, the linkage relationship is closer and there is a remarkable volatility in INE return in the second half year of 2020 .

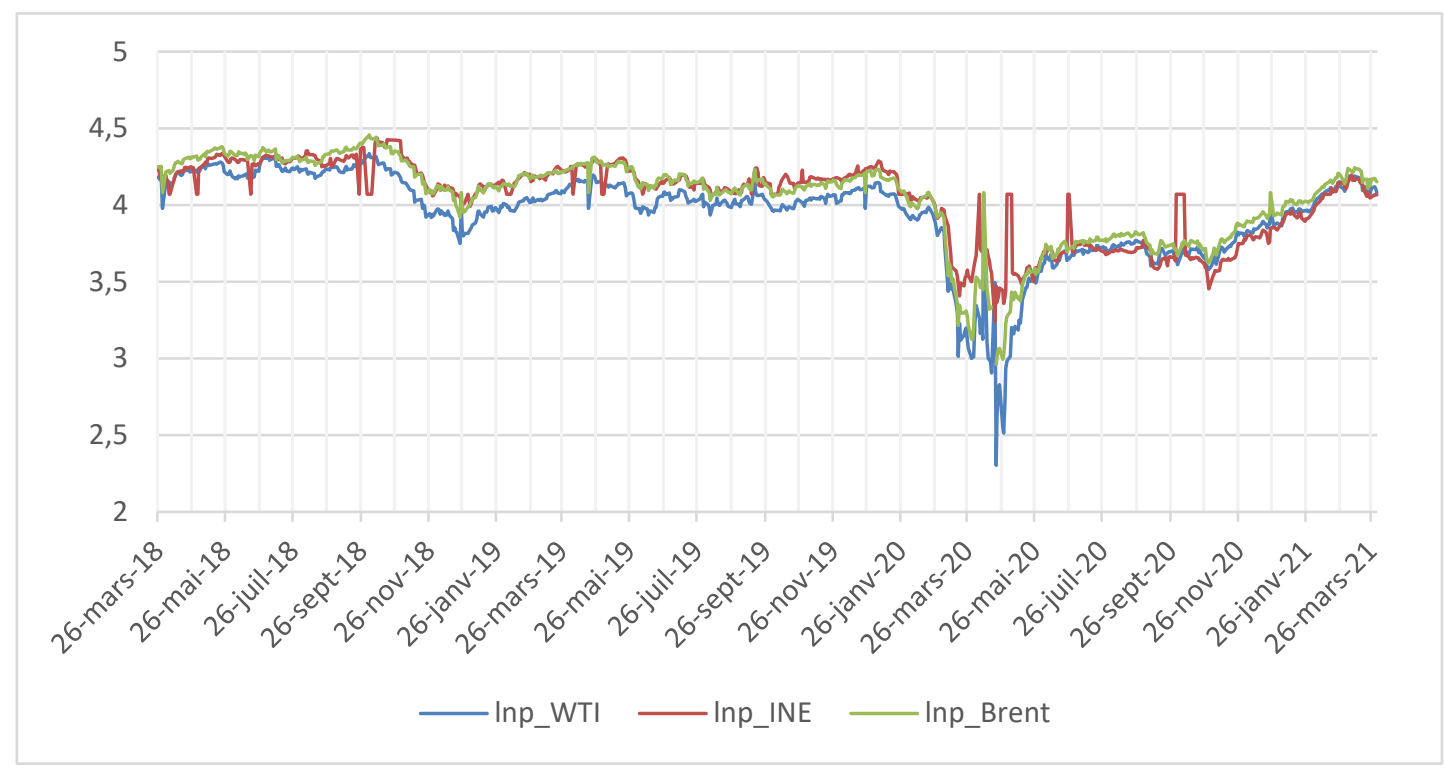

Figure 3. Log price of three international crude oil futures

Source: CME group

Based on the above fact, we can guess that there is a structural break in these time series. Similar with the COVID-19 crisis, Perron (1989) carried out tests of the unit root hypothesis against the alternative hypothesis of trend stationarity with a break in the trend occurring at the Great Crash of 1929 or at the oil price shock of 1973. However, Zivot and Donald (1992) argued that Perron's choice of break points are based on the pre-observation of the data and hence problems associated with pre-testing are applicable to his methodology. Therefore, question this exogeneity assumption and conduct unit test which treat the structural break as an exogenous occurrence. Here, we apply the Zvoit-Andrews unit root test to confirm the structural break as the specific point of the COVID-19 outbreak. The null hypothesis is that the price series is integrated without an exogenous break.

After unit root test, it is a common practice to research on long-term equilibrium relationships between different variables on financial markets.However ,if there is a structural break, the hypothesis that the residuals of the Engle and Granger model are I(1) will not be rejected, 
and therefore to decide on non-cointergration, whereas,there may be a shift in regime in the cointegration relationship. To help solve this problem, Gregory and Hansen(1996 a) used an approach to modify the Engle and Granger model to allow a change in structure in the longterm relationship. In this test, the null hypothesis is the non-cointegration while the alternative hypothesis is there is a cointegration relation with a structural change in the constant and/or the slope of a linear trend following a major shock.

If a cointegration relationship with structural break do exists, the vector error correction is traditionally estimated to descibe the evolution of the variables in the short-term and longterm. Price discovery is the dynamic process by which market prices incorporate new Information. Based on VECM, there are two widely used measures of price discovery for multiple markets: Information share (IS) which defined by Hasbrouck (1995) as the proportion of the efficient price innovation variance attributable to the market; Component Share (CS) proposed by Booth, So, and Tse (1999), Chu, Hsieh, and Tse (1999), and Harris, Mclnish, and Wood (2009), measuring one market's contribution to price discovery during the process of forming the efficient price innovation. IS focuses on the variance of the efficient price innovation, and measures what proportion of the efficient price variance can be attributed to the innovations from different markets. The CS approach, on the other hand, focuses on the composition of the efficient price innovation and measures a market's contribution to price discovery as its contribution to the efficient price innovation. In our paper, to explore the different influence of COVID-19 to these three crude oil futures markets on price discovery, we apply the IS and CS calculation to get a clear interpretation of price discovery.

\subsection{Gregory and Hansen Tests}

To test the existence of a cointegration relation which allows for the possibility of regime shifts, Gregory and Hansen (1996) propose ADF-, Z-, and Z-type tests designed to test the null of no cointegration against the alternative of cointegration in the presence of a possible regime shift. In in their article, to estimate the structural effect, they introduced the dummy variable: $D_{t \tau}=0$ if $t \leq[n \tau]$ and otherwise 1 and [.] represents the integer part. where the unknown parameter $\tau \in(0,1)$ denotes the (relative) timing of the change point. Assuming that the observed data is $y_{t}=\left(y_{1}, y_{2}\right)$ where $y_{1}$ is real-valued and $y_{2}$ is a vector with $\mathrm{m}$ components, they considered three alternative types of regression models where the intercept and/or slope coefficients have a single break of unknown timing. The standard cointegration model of Engle and Granger is written:

$$
Y_{1 t}=\mu_{1}+\alpha^{\prime} Y_{2 t}+\varepsilon_{t}
$$

The alternative models are written:

(i) A model with level shift (C)

$$
Y_{1 t}=\mu_{1}+\mu_{2} D_{t \tau}+\alpha^{\prime} Y_{2 t}+\varepsilon_{t}
$$


(ii) A model with a liner trend incorporating a change in level(C/T)

$$
Y_{1 t}=\mu_{1}+\mu_{2} D_{t \tau}+\beta t+\alpha^{\prime} Y_{2 t}+\varepsilon_{t}
$$

(iii) Regime shift(C/S)

$$
Y_{1 t}=\mu_{1}+\mu_{2} D_{t \tau}+\beta t+\alpha^{\prime} Y_{2 t}+\alpha^{\prime} Y_{2 t} D_{t \tau}+\varepsilon_{t}
$$

When it comes to test statistics, Gregory and Hansen use modified values of the $Z_{\alpha}$ and $Z_{t}$ statistics of Phillips (1987) and of augmented Dickey-Fuller(ADF). Their statistics are the smallest values of the preceding statistics, across all values of $\tau \in T$. These statistics are:

$$
\begin{aligned}
Z_{\alpha}^{*} & =\inf _{(\tau \in \mathrm{T})} Z_{\alpha}(\tau) \\
Z_{t}^{*} & =\inf _{(\tau \in \mathrm{T})} Z_{t}(\tau) \\
A D F^{*} & =\inf _{(\tau \in \mathrm{T})} A D F(\tau)
\end{aligned}
$$

Where $\tau$ located the shift in regime and $\mathrm{T}$ a closed interval of $(0,1)$. In our research, we used the interval $\mathrm{T}=[0.15,0.85]$ proposed by Gregory and Hansen.

\subsection{Vector error correction model}

Let $P_{t}=\left(p_{1, t}, p_{2, t}\right)^{\prime}$ denote a $2 * 1$ vector of log price for the asset from the two markets. We assume we assume that $P_{t}$ is cointegrated with known cointegrating vector $\beta=(1,-1)^{\prime}$ so that $\beta^{\prime} P_{t}=p_{1 t}-p_{2 t}$ is intergrated of order zero,or I $(0)$. Based upon Engle and Granger (1987), the representation of the vector error correction model in general terms can be shown as:

$$
\Delta p_{t}=\alpha\left(\beta^{\prime} p_{t-1}-\mu\right)+\sum_{k=1}^{k-1} \Gamma_{k} \Delta p_{t-k}+e_{t}
$$

Where $\mu=\mathrm{E}\left(\beta^{\prime} p_{t-1}\right)$. The vector $\alpha$ is a matrix of error correction coefficients which imply the adjustment speed to the deviations from the long-run equilibrium. For a bivariate case, $\alpha$ contains two coefficients, $\alpha_{1}$ and $\alpha_{2}$, for market 1 and market 2 . If $\alpha_{2}$ is larger than $\alpha_{1}$, it implies that market 1 leads market 2 in the long run. Market 2 leads market 1 if the other way around. $\Gamma_{k}$ contains coefficients for short-term adjustment. $e_{t}$ is a zero-mean vector of serially uncorrelated innovations with covariance matrix $\Omega$ such that:

$$
\Omega=\left(\begin{array}{cc}
\sigma_{1}^{2} & \rho \sigma_{1} \sigma_{2} \\
\rho \sigma_{1} \sigma_{2} & \sigma_{2}^{2}
\end{array}\right)
$$


Here $\sigma_{1}{ }^{2}, \sigma_{2}^{2}$ are respectively the variance of $e_{1 t}$ and $e_{2 t}$ and $\rho$ is the correlation between $e_{1 t}$ and $e_{2 t}$.

According to Hasbrouck (1995) information share, we transform the VECM in Equation (1) into a vector moving average (VMA)

$$
\Delta p_{t}=\Psi(L) e_{t}
$$

And its integrated form

$$
\Delta p_{t}=\Psi(1) \sum_{s=1}^{t} e_{s}+\Psi^{*}(\mathrm{~L}) e_{t}
$$

Where $\Psi(1)$ is the impact matrix which represents the sum of all moving average coefficients. $\Psi(1) e_{t}$ is the long-run impact of an innovation on each of the prices. If the rows of impact matrix are identical, the long-run impact is the same for all market, which has been proved by Baillie et al. (2002), de Jong (2002) and Hasbrouck (1995). We denote $\psi=\left(\psi_{1}, \psi_{2}\right)$ as the common row vector in $\Psi(1)$.

\subsection{Information Share (IS)}

Information Share was interpreted as measuring "who moves first in the process of price adjustment". Hasbrouck (1995) decomposes the variance of the common factor innovations. Based on the share of the variance of $\psi e_{t}$ that is attributable to the underlying market, the IS of market $i$ is defined as:

$$
I S_{i}=\frac{\psi_{i}^{2} \sigma_{i}^{2}}{\psi \Omega \psi^{\prime}}=\frac{\psi_{i}^{2} \sigma_{i}^{2}}{\psi_{i}^{2} \sigma_{i}^{2}+\psi_{2}^{2} \sigma_{2}^{2}}, \mathrm{i}=1,2
$$

Where $\psi_{i}$ is the $\mathrm{i}$ th element of $\Psi$, var $\left(\psi e_{t}\right)=\psi \Omega \psi^{\prime}$ and $\Omega$ is the diagonal matrix which means there are no correlation between markets. By construction, $I S_{1}+I S_{2}=1$, it is clear that a low (high) information share for market $i$ implies a small (large) reaction to the arrival of new information about fundamental value.

Hasbrouck (1995) suggested to compute the Cholesky decomposition of $\Omega$ and measure the IS using the orthogonalized innovations if $\Omega$ is non-diagonal. In fact, Cholesky factorization depends the orders of variables. Hence, we need to take into account different variable orders to obtain the upper and lower bounds for information share of each market. For a bivariate case, test $\mathrm{F}$ be a lower triangular matrix such that $\mathrm{FF}^{\prime}=\Omega$, then the IS for the $\mathrm{i}$ th market is:

$$
I S_{i}=\frac{\left(\left[\psi^{\prime} F\right]_{i}\right)^{2}}{\psi \Omega \psi^{\prime}}
$$

Where $\left[\psi^{\prime} F\right]_{i}$ is the ith element of the row of matrix $\psi^{\prime}$ F. Denote

$$
\mathrm{F}=\left(\begin{array}{cc}
f_{11} & 0 \\
f_{12} & f_{22}
\end{array}\right)=\left(\begin{array}{cc}
\sigma_{1} & 0 \\
\rho \sigma_{2} & \sigma_{2}\left(1-\rho^{2}\right)^{1 / 2}
\end{array}\right)
$$


When market one is in the first variable, the calculated information share is its upper limit; when it is in the last variable, the calculated information share is its lower limit. The average of the upper and lower limits is its average share of information (Yan \& Zivot, 2007)

Upper bounds of information share of Market1:

$$
I S_{u}=\frac{\left(\alpha_{2} \sigma_{1}-\alpha_{1} \sigma_{2} \rho\right)^{2}}{\alpha_{2}^{2} \sigma_{1}^{2}-2 \rho \alpha_{1} \alpha_{2} \sigma_{1} \sigma_{2}+\sigma_{2}^{2} \alpha_{1}^{2}}
$$

Lower bounds of information share of Market1:

$$
I S_{l}=\frac{\alpha_{2}^{2} \sigma_{1}^{2}\left(1-\rho^{2}\right)}{\alpha_{2}^{2} \sigma_{1}^{2}-2 \rho \alpha_{1} \alpha_{2} \sigma_{1} \sigma_{2}+\sigma_{2}^{2} \alpha_{1}^{2}}
$$

\subsection{Component Share (CS)}

Component Share is proposed by Booth et al. (1999), Chu et al. (1999), and Harris et al. (2009) to measure one market's contribution to price discovery which using the permanenttransitory(PT) component decomposition of Gonzalo and Granger (1995). The PT decomposition of $p_{t}$ is defined as follows:

$$
p_{t}=A f_{t}+Z_{t}
$$

Where $f_{t} \sim I(1)$ is a permanent common factor while $Z_{t}$ is the transitory component which is a short-term stationary factor. A is a coefficient matrix. $Z_{t}$ does not Granger causes $f_{t}$. Following Gonzalo and Granger(1995), $f_{t}$ can be expressed as a linear combination of prices. Thus

$$
f_{t}=\gamma^{\prime} p_{t}
$$

As Gonzalo and Granger (1995) defined,

$$
\gamma=\left(\alpha_{\perp}^{\prime} \beta_{\perp}\right)^{-1} \alpha_{\perp}^{\prime}
$$

where $\alpha_{\perp}$ is an orthogonal matrix to the error-correction coefficient matrix $\alpha$ which can be used to measure the contribution of each market to the price discovery process. $\beta_{\perp}$ is an orthogonal matrix to the co-integrating matrix $\beta . \alpha_{\perp}$ and $\beta_{\perp}$ are scaled vectors to 1 . For two markets case, $\alpha_{\perp}$ and $\beta_{\perp}$ are $2 * 1$ vectors such that $\alpha_{\perp}^{\prime} \alpha=0$ and $\beta_{\perp}^{\prime} \beta=0$. Since $\beta=$ $(1,-1)^{\prime}$, one choice for $\beta_{\perp}$ is $\mathbf{1}=(1,1)^{\prime}$, implying $\gamma=\left(\alpha_{\perp}^{\prime} \mathbf{1}\right)^{-1} \alpha_{\perp}^{\prime}$ so that the permanent component weights $\gamma_{i}=\alpha_{\perp, i} /\left(\alpha_{\perp, 1}+\alpha_{\perp, 2}\right)$ for $\mathrm{i}=1,2$ which was proposed by Booth et al. (1999), Chu et al. (1999), and Harris et al. (2009) as component share(CS) to measure price discovery.

$$
C S_{i}=\alpha_{\perp, i} /\left(\alpha_{\perp, 1}+\alpha_{\perp, 2}\right), \mathrm{i}=1,2
$$


Where $f_{t}=\gamma^{\prime} p_{t} \sim I(1)$ is the permanent component while $Z_{t} \sim I(0)$ is the transitory component. $\gamma=\left(\alpha_{\perp}^{\prime} \beta_{\perp}\right)^{-1} \alpha_{\perp}^{\prime}$, where $\alpha_{\perp}$ and $\beta_{\perp}$ are $2 * 1$ vectors such that $\alpha_{\perp}^{\prime} \alpha=0$ and $\beta_{\perp}^{\prime} \beta=0$. Since $\beta=(1,-1)^{\prime}$, one choice for $\beta_{\perp}$ is $\mathbf{1}=(1,1)^{\prime}$, implying $\gamma=\left(\alpha_{\perp}^{\prime} \mathbf{1}\right)^{-1} \alpha_{\perp}^{\prime}$ so that the permanent component is a weighted average of observed prices with component weights. So, the component share (CS) measuring price discovery in market i:

$$
C S_{i}=\alpha_{\perp, i} /\left(\alpha_{\perp, 1}+\alpha_{\perp, 2}\right), \mathrm{i}=1,2
$$

Baillie et al. (2002)noted that since $\alpha_{\perp}^{\prime} \alpha=0, \alpha=\left(\alpha_{1}, \alpha_{2}\right)^{\prime}$, then $\alpha_{\perp}^{\prime}=\left(\alpha_{2},-\alpha_{1}\right)$, such that Component Share may also be expressed in terms of the elements of the error correction coefficient vector $\alpha$ :

$$
C S_{1}=\frac{\alpha_{2}}{\alpha_{2}-\alpha_{1}} \quad C S_{2}=\frac{-\alpha_{1}}{\alpha_{2}-\alpha_{1}}
$$

Equation (22) show that price discovery occurs entirely in market $\mathrm{i}$ if $\alpha_{i}=0$; If the contemporary price change in market $i$ does not respond to the lagged disequilibrium error $\beta^{\prime} p_{t-1}=p_{1 t-1}-p_{2 t-1}$. In this respect, $C S_{1}$ reflects how sensitive market 2 is, relative to market 1 , to lagged transitory shocks and vice versa.

\section{Empirical Analysis}

Before discussing more in depth the interpretation of the IS and CS between three crude oil futures market, we perform unit root test and cointegration test with structural break. On this basis, we can establish the IS and CS model to study the contribution of different crude oil markets to price discovery process before and after the outbreak of COVID-19

\subsection{Unit root test and stationary tests}

\begin{tabular}{|c|c|c|c|c|c|}
\hline & \multicolumn{2}{|c|}{ Critical Values } & Ln(P_WTI) & Ln(P_Brent) & Ln(P_INE) \\
\hline \multicolumn{6}{|c|}{ Augmented Dickey-Fuller Test (H0:Ln(P_X) has a unit root) } \\
\hline \multicolumn{6}{|c|}{ Exogenous: Constant, Linear Trend } \\
\hline \multirow[t]{3}{*}{ t- statistic } & $1 \%$ level & $\begin{array}{l}- \\
3.970014\end{array}$ & \multirow[t]{3}{*}{-2.913383} & \multirow[t]{3}{*}{-1.898092} & \multirow[t]{3}{*}{-2.511657} \\
\hline & $5 \%$ level & $\begin{array}{l}- \\
3.415663\end{array}$ & & & \\
\hline & $10 \%$ level & $\begin{array}{l}- \\
3.130077\end{array}$ & & & \\
\hline
\end{tabular}

Table 2. Unit root test and stationary tests for log price series 
Exogenous: Constant, Linear Trend

\begin{tabular}{|l|l|l|l|l|l|}
\hline t-statistic & $1 \%$ level & 0.216000 & $0.216036^{* * * *}$ & $0.226274^{* * *}$ & $0.213206^{* *}$ \\
\cline { 2 - 3 } & $5 \%$ level & 0.146000 & & & \\
\cline { 2 - 4 } & $10 \%$ level & 0.119000 & & & \\
\hline
\end{tabular}

Note: The superscripts"***"',**'"**"indicate the degree of significance associated with rejection of null hypothesis at the level of $1 \%, 5 \%$ and $1 \%$ respectively

To check the stationarity of the three crude oil futures time series, the study performs Augmented Dickey-Fuller (ADF) unit root test and Kwiatkowski-Phillips-Schmidt-Shin (KPSS) Test. The null hypothesis for ADF test is that the time series has one unit root and hence, not stationary while the null hypothesis for KPSS test is that the time series is stationary. From the tests for log price series, we cannot reject the null hypothesis of ADF and reject the null hypothesis of KPSS which means that these three crude oil prices are all not stationary. The post oil crash literature provided alternative arguments following the paper by Perron (1989), who has shown that the unite tests have low power in applications to processes with level shifts. We mentioned before that there is a drop in oil prices and it's known that the unit root tests do not distinguish between the stationary processes with local trends and nonstationary processes with global trends. Hence, the unite root tests tend to accept the null hypothesis.

Table 3. Zviot-Andrews Unit Root Test

Null Hypothesis: $\operatorname{Ln}\left(\mathrm{P}_{-} \mathrm{X}\right)$ has a unit root with a structural break in both the intercept and trend

\begin{tabular}{|l|l|l|l|}
\hline Variables & Ln(P_WTI $)$ & Ln(P_Brent) & Ln(P_INE) \\
\hline $\begin{array}{l}\text { Zivot-Andrews T- } \\
\text { Statistics }\end{array}$ & $-5.344566 * * *$ & $-6.528970 * * *$ & $-6.720717 * * *$ \\
\hline Break Date & $3 / 06 / 2020$ & $3 / 06 / 2020$ & $3 / 06 / 2020$ \\
\hline
\end{tabular}

Note: The superscripts"***"”***"'**"indicate the degree of significance associated with rejection of null hypothesis at the level of $1 \%, 5 \%$ and $10 \%$ respectively

A simple way to solve the problem is to conduct the Zivot-Andrews unit root test to confirm the structural break as the specific point of the COVID-19 breakout. The null hypothesis is that the price series is integrated without an exogenous break. From the ZivotAndrews test results in table 3, it shows that the $t$ statistics favors the rejection of the null hypothesis at $1 \%$ level of significance for the price series and the break date is $6^{\text {th }}$ of March ,2020.As a result, we take this date as a turning point to split our research sample into two subperiods: Pre-COVID(26/03/2018-05/03/2020) and Post-COVID(06/03/2020$31 / 03 / 2021)$. We compared the difference of the three international crude oil markets before 
and after the breakout of the COVID-19. Table 4 lists the descriptive statistics of the specific variables.

Table 4. Descriptive Statistics of daily price

\begin{tabular}{|c|c|c|c|c|c|c|c|c|c|}
\hline \multirow[t]{2}{*}{ Variable } & \multicolumn{3}{|c|}{ Lnp_INE } & \multicolumn{3}{|c|}{ Lnp_WTI } & \multicolumn{3}{|c|}{ Lnp_BRENT } \\
\hline & $\begin{array}{l}\text { Whole } \\
\text { Sample }\end{array}$ & $\begin{array}{l}\text { Pre- } \\
\text { COVID }\end{array}$ & $\begin{array}{l}\text { Post- } \\
\text { COVI } \\
\text { D }\end{array}$ & $\begin{array}{l}\text { Whole } \\
\text { Sample }\end{array}$ & $\begin{array}{l}\text { Pre- } \\
\text { COVID }\end{array}$ & $\begin{array}{l}\text { Post- } \\
\text { COVID }\end{array}$ & $\begin{array}{l}\text { Whole } \\
\text { Sample }\end{array}$ & $\begin{array}{l}\text { Pre- } \\
\text { COVID }\end{array}$ & $\begin{array}{l}\text { Post- } \\
\text { COVID }\end{array}$ \\
\hline Mean & 4.0418 & 4.1952 & 3.7620 & 3.9447 & 4.0877 & 3.6830 & 4.0474 & 4.2008 & 3.7678 \\
\hline Maximum & 4.4369 & 4.4369 & 4.1965 & 4.3361 & 4.3361 & 4.1910 & 4.4577 & 4.4577 & 4.2432 \\
\hline Minimum & 3.3596 & 3.9132 & 3.3596 & 2.3036 & 3.7502 & 2.3036 & 2.9617 & 3.9118 & 2.9617 \\
\hline Std. Dev. & 0.2509 & 0.0985 & 0.1970 & 0.2920 & 0.1192 & 0.3309 & 0.2773 & 0.1117 & 0.2707 \\
\hline Skewness & -0.7956 & 0.0498 & 0.5443 & -1.8438 & -0.0089 & -1.1801 & -1.2807 & 0.0051 & -0.5499 \\
\hline Kurtosis & 2.4378 & 2.5427 & 2.3806 & 7.6618 & 2.2563 & 4.9060 & 4.5078 & 2.2992 & 3.3125 \\
\hline
\end{tabular}

Table 5 shows the descriptive statistical analysis results of the logarithmic price of the three crude oil markets respectively. As we expected, the results show that after the outbreak of the COVID-19 the mean of three crude oil futures markets decreases on account of the decreased demand while the standard deviation of log price increases obviously which means the market fluctuates significantly due to the COVD-19. From the Standard Deviation results, we can see that WTI price series fluctuate the most, especially in the post-COVID period which also fits the actual situation well.

\subsection{Cointegration tests with structural break}

Table 5. Testing for regime shifts in crude oil markets with Gregory and Hansen's cointegration tests

\begin{tabular}{|l|c|c|c|c|c|c|}
\hline \multicolumn{6}{|l|}{ Dependent Variable: Brent ; Independent Variable: INE } \\
\hline & ADF* & ADF Break & $Z_{\alpha}^{*}$ & $Z_{\alpha}$ Break & $Z_{t}^{*}$ & $Z_{t}$ Break \\
\hline C & -7.115218 & $5 / 12 / 2020$ & -233.3461 & $5 / 12 / 2020$ & -11.85103 & $5 / 12 / 2020$ \\
\hline C/T & -7.210932 & $5 / 12 / 2020$ & -240.0661 & $5 / 12 / 2020$ & -12.06450 & $5 / 12 / 2020$ \\
\hline C/S & -7.714931 & $5 / 12 / 2020$ & -274.1127 & $5 / 11 / 2020$ & -13.04714 & $5 / 12 / 2020$ \\
\hline Dependent Variable: WTI ; Independent Variable: INE \\
\hline C & -6.679129 & $5 / 22 / 2020$ & -204.9477 & $5 / 12 / 2020$ & -11.07939 & $5 / 12 / 2020$ \\
\hline C/T & -6.718419 & $5 / 22 / 2020$ & -206.4793 & $5 / 12 / 2020$ & -11.14513 & $5 / 12 / 2020$ \\
\hline
\end{tabular}




\begin{tabular}{|l|c|c|c|c|c|c|}
\hline C/S & -7.325701 & $5 / 19 / 2020$ & -257.8656 & $5 / 12 / 2020$ & -12.63212 & $5 / 12 / 2020$ \\
\hline \multicolumn{5}{|l|}{ Dependent Variable: WTI; Independent Variable: Brent } \\
\hline C & -4.715935 & $5 / 27 / 2020$ & -103.1981 & $5 / 12 / 2020$ & -7.396729 & $5 / 12 / 2020$ \\
\hline C/T & -4.697390 & $5 / 27 / 2020$ & -98.01141 & $5 / 29 / 2020$ & -7.217182 & $5 / 12 / 2020$ \\
\hline C/S & -4.992884 & $5 / 27 / 2020$ & -105.5512 & $5 / 12 / 2020$ & -7.528660 & $5 / 12 / 2020$ \\
\hline Dependent Variable: INE ; Independent Variable: Brent \\
\hline C & -8.152040 & $5 / 12 / 2020$ & -265.2832 & $5 / 08 / 2020$ & -12.68888 & $5 / 08 / 2020$ \\
\hline C/T & -13.08795 & $5 / 12 / 2020$ & -274.8498 & $5 / 11 / 2020$ & -12.96169 & $5 / 08 / 2020$ \\
\hline C/S & -13.28543 & $5 / 12 / 2020$ & -284.5190 & $5 / 11 / 2020$ & -13.21278 & $5 / 12 / 2020$ \\
\hline Dependent Variable: INE ; Independent Variable: WTI & \\
\hline C & -9.150566 & $4 / 28 / 2020$ & -233.2698 & $5 / 08 / 2020$ & -11.82015 & $5 / 12 / 2020$ \\
\hline C/T & -9.139825 & $4 / 28 / 2020$ & -236.4836 & $5 / 12 / 2020$ & -11.92202 & $5 / 12 / 2020$ \\
\hline C/S & -11.08140 & $5 / 12 / 2020$ & -267.1994 & $5 / 12 / 2020$ & -12.78357 & $5 / 12 / 2020$ \\
\hline Dependent Variable: Brent ; Independent Variable: WTI \\
\hline C & -4.633316 & $5 / 27 / 2020$ & -92.46942 & $5 / 12 / 2020$ & -6.990097 & $5 / 12 / 2020$ \\
\hline C/T & -4.498004 & $5 / 21 / 2020$ & -89.24019 & $5 / 12 / 2020$ & -6.862034 & $5 / 12 / 2020$ \\
\hline C/S & -4.939771 & $5 / 26 / 2020$ & -102.9376 & $5 / 12 / 2020$ & -7.425560 & $5 / 12 / 2020$ \\
\hline
\end{tabular}

Table 5 gives the results of the Gregory and Hansen tests with the determination of the structural breakpoint for WTI , Brent and INE during the period from 2018 to 2021. The three statistics $\mathrm{ADF}^{*}, Z_{\alpha}^{*}$ and $Z_{t}^{*}$ clearly indicate that there is cointegration with the three alternative models $(\mathrm{C}),(\mathrm{C} / \mathrm{T})$ and $(\mathrm{C} / \mathrm{S})$. According to the $\mathrm{ADF}^{*}, Z_{\alpha}^{*}$ and $Z_{t}^{*}$, the structural break date estimated on the basis of the three models is mainly $12^{\text {th }}$ of May,2020. We noticed that most cities including Wuhan has lift the lockdown restrictions in China by May, 2020 , many tourist attractions reopened and the national economy has entered the stage of recovery which drives oil demand without doubt. However, with respect to Europe, the European Commission invited Schengen Member States and Schengen Associated States to extend the temporary restriction on non-essential travel for another 30 days at the beginning of May. At this point, where America is concerned, after the negative price at the end of April, WTI was still under a high volatility. Based on these facts, it is not hard to understand why the structural break in cointegration relationship tested by $\mathrm{ADF}^{*}, Z_{\alpha}^{*}$ and $Z_{t}^{*}$ mainly refer to April or May. 


\subsection{IS and CS measures}

After the stationary tests and cointegration tests, we expect to figure out the different degree of these three crude oil futures market contribution to the international price forming process which is called price discovery process. Price discovery is the process by which security markets attempt to identify permanent changes in equilibrium transaction prices. The two method we applied here to explore price discovery of different crude oil markets are information share (IS) and component share (CS). IS is defined to measure in terms of volatility while CS is used to measure the speed of each market moving to the equilibrium price.

Table 6. IS model information share for international crude oil markets (lag.max=120)

\begin{tabular}{|c|c|c|c|c|}
\hline & & Upper bound & Lower bound & Midpoint \\
\hline \multicolumn{5}{|c|}{ Whole sample $(26 / 03 / 2018-31 / 03 / 2021)$} \\
\hline \multirow[t]{2}{*}{ (WTI,INE) } & WTI & $72.47 \%$ & $57.41 \%$ & $64.94 \%$ \\
\hline & INE & $42.59 \%$ & $27.53 \%$ & $35.06 \%$ \\
\hline \multirow[t]{2}{*}{ (Brent,INE) } & Brent & $96.35 \%$ & $88.22 \%$ & $92.29 \%$ \\
\hline & INE & $11.78 \%$ & $3.65 \%$ & $7.71 \%$ \\
\hline \multirow[t]{2}{*}{ (WTI,Brent) } & WTI & $46.71 \%$ & $22.95 \%$ & $34.83 \%$ \\
\hline & Brent & $77.05 \%$ & $53.29 \%$ & $65.17 \%$ \\
\hline \multicolumn{5}{|c|}{ The pre-covid period $(26 / 03 / 2018-05 / 03 / 2020)$} \\
\hline \multirow[t]{2}{*}{ (WTI,INE) } & WTI & $99.90 \%$ & $98.37 \%$ & $99.14 \%$ \\
\hline & INE & $1.63 \%$ & $0.10 \%$ & $0.87 \%$ \\
\hline \multirow[t]{2}{*}{ (Brent,INE) } & Brent & $99.37 \%$ & $96.87 \%$ & $98.12 \%$ \\
\hline & INE & $3.13 \%$ & $0.63 \%$ & $1.88 \%$ \\
\hline \multirow[t]{2}{*}{ (WTI,Brent) } & WTI & $99.94 \%$ & $7.74 \%$ & $53.84 \%$ \\
\hline & Brent & $92.26 \%$ & $0.06 \%$ & $46.16 \%$ \\
\hline \multicolumn{5}{|c|}{ The post-covid period $(06 / 03 / 2020-31 / 03 / 2021)$} \\
\hline \multirow[t]{2}{*}{ (WTI,INE) } & WTI & $96.85 \%$ & $93.93 \%$ & $95.39 \%$ \\
\hline & INE & $6.07 \%$ & $3.15 \%$ & $4.61 \%$ \\
\hline \multirow[t]{2}{*}{ (Brent,INE) } & Brent & $88.38 \%$ & $86.52 \%$ & $87.45 \%$ \\
\hline & INE & $13.48 \%$ & $11.62 \%$ & $12.55 \%$ \\
\hline
\end{tabular}




\begin{tabular}{|l|l|l|l|r|}
\hline (WTI,Brent) & WTI & $96.62 \%$ & $17.09 \%$ & $56.86 \%$ \\
\cline { 2 - 5 } & Brent & $82.91 \%$ & $3.38 \%$ & $43.15 \%$ \\
\hline
\end{tabular}

In terms of information share, Table 6 presents the results of maximum, minimum and average information share of WTI, BRENT, INE. We use the automatic lag selection based on the AIC criterion, and specify an upper bound for the maximum number of lags to be used for VECM estimation. Here we set the maximum number of lags 120 as Aggarwal and Thomas (2019) did. For the sake of robustness of results, we also conduct the model by setting the number of lags as 60 . The results are attached in the appendix. The empirical results of full samples indicates that the price discovery capability (average information share, Yan and Zivot (2007) of WTI and BRENT is stronger than INE market. The table shows, in the group of (lnp_WTI, lnp_INE), the information share of WTI market accounts for $64.94 \%$ and that of INE market is $35.06 \%$. That means in the long run, a coordinated movement between the two markets is dominated by WTI futures markets. In other words, WTI futures markets contribute $64.94 \%$ of the price discovery and the INE futures market contributed $35.06 \%$. Similarly, in the group of (lnp_BRENT, Inp_INE), it is the BRENT market that plays a leading role. Between the group of (lnp_WTI , Inp_Brent) which are two basic world benchmarks, Brent also contributes more than WTI in the long run. The above results show that since the launch of INE crude oil futures, Brent price mainly plays a leading role in price discovery in international crude oil price.

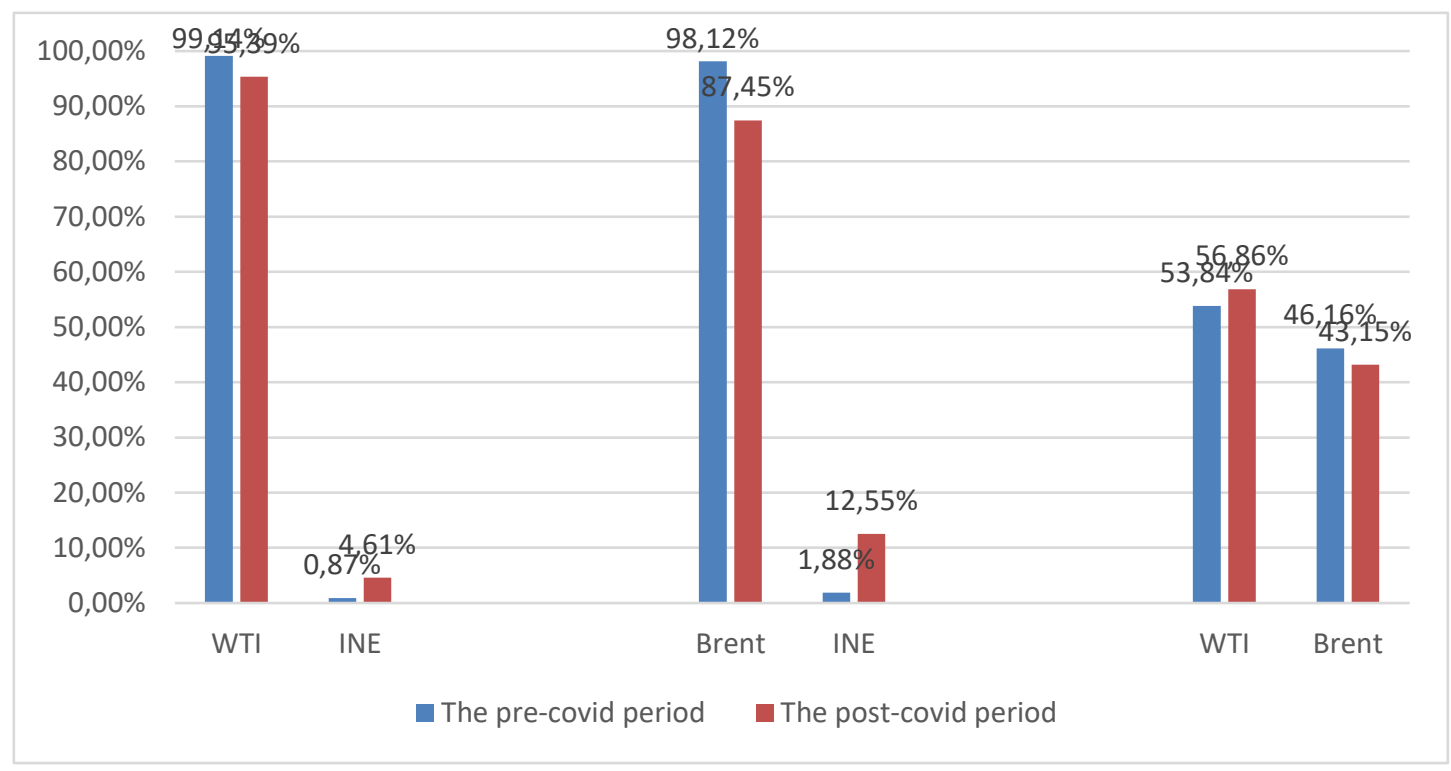

Figure 4. Comparison of IS of three markets before and after the COVID-19

In addition, we further analyzed the difference of information share before and after the outbreak. We took March 6, 2020 as the turning point to divide the whole sample into two subsamples. As the figure 4 shows, we found that the information share of INE market has 
increased slightly in the post-covid period compared with the pre-covid period. Although limited by the number of samples, it also proves that its price discovery function has been improved after the outbreak of COVID. After this outbreak, the effective implementation of epidemic prevention measures by the Chinese government has increased market confidence as well as the trading volume of crude oil futures in INE, thus enhancing the realization of price discovery function in Shanghai crude oil futures market. On the contrary, the information share of WTI and Brent crude oil futures market has decreased in the three combined markets, indicating that the information advantage of WTI and Brent futures market has decreased after the epidemic, but they still occupy an absolute dominant position. These results can be supported by the change of world oil demand before and after the COVID-19 outbreak. As previewed as by the GDP growth and the oil demand changes by regional areas( Table 1 and Figure 5), we observe a significant change in world oil demand in 2020Q1 and Q2. Since the end of 2019, oil demand has experienced an obvious decrease in America, Europe and China because of the pandemic. Among that, the slowdown of oil demand in Europe is larger than in America. After 2020Q2, the word oil demand has been increasing and the oil demand of China has increased more rapidly than America and Europe which can be used to explain why the IS of INE increased slightly after the COVID.

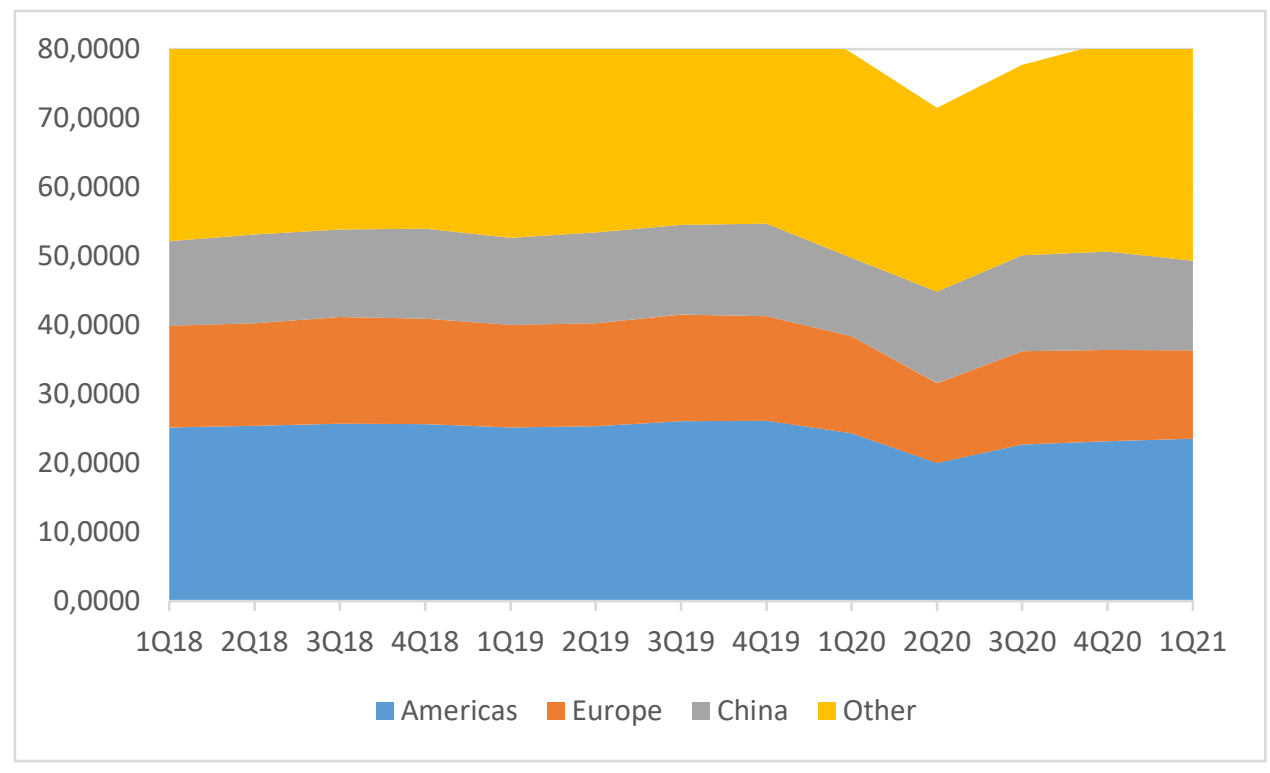

Figure 5. Quarterly World Oil Demand from 2018 to 2021

In the group of (lnp_WTI , lnp_Brent), the information share of WTI market is always larger than Brent market no matter before or after the outbreak of COVID, which means WTI price plays a leading role of Brent Price in long run. Additionally, the IS of WTI is larger in the post-covid period than in the pre-covid period probably because the oil demand recovery speed of Europe is slower than that of America as Figure 5 shows. The aboveoutcomes prove the robustness of the results of the average information share model of the full sample, and 
also show that the sudden external shock caused by the epidemic plays a regulatory role in the price discovery of the three major international crude oil markets.

Table 7. CS model information share for international crude oil markets (lag.max=120)

\begin{tabular}{|l|l|l|l|l|l|l|}
\hline \multirow{2}{*}{} & \multicolumn{2}{|c|}{ (WTI,INE) } & \multicolumn{2}{c|}{ (Brent,INE) } & \multicolumn{2}{c|}{ (WTI,Brent) } \\
\cline { 2 - 7 } & WTI & INE & Brent & INE & WTI & Brent \\
\hline $\begin{array}{l}\text { Whole sample } \\
(26 / 03 / 2018-31 / 03 / 2021)\end{array}$ & $58.80 \%$ & $41.20 \%$ & $85.91 \%$ & $14.09 \%$ & $34.89 \%$ & $65.11 \%$ \\
\hline $\begin{array}{l}\text { The pre-covid period } \\
(26 / 03 / 2018- \\
05 / 03 / 2020)\end{array}$ & $97.59 \%$ & $2.41 \%$ & $94.57 \%$ & $5.43 \%$ & $91.26 \%$ & $8.74 \%$ \\
\hline $\begin{array}{l}\text { The post-covid period } \\
(06 / 03 / 2020- \\
31 / 03 / 2021)\end{array}$ & $85.20 \%$ & $14.80 \%$ & $80.97 \%$ & $19.03 \%$ & $69.66 \%$ & $30.34 \%$ \\
\hline
\end{tabular}

When it comes to component share, the results of CS is generally similar with IS. For the whole sample, Brent contributes more share than WTI and then INE follows. It means that during the process of price discovery, Brent market moves to the equilibrium price faster than Brent. INE is the market which moves to implicit efficient price most slowly. Compared with the pre-covid period, the component share of INE increased slightly no matter in the WTI and INE group or the Brent and INE group after the outbreak of COVID-19. In the group of WTI and Brent, we can also notice the phenomenon that the dominant role transfer from the Brent to WTI in the short run compared with in the long run. After the negative oil price event, the information share of the WTI futures market did not reduce but increased after the pandemic. We believe that the low price and high volatility of futures markets of WTI may be conducive to attracting more market participants to speculate and hedge, so it's likely that the price discovery function of futures markets is improved because of the large trading volume in the short-term. 


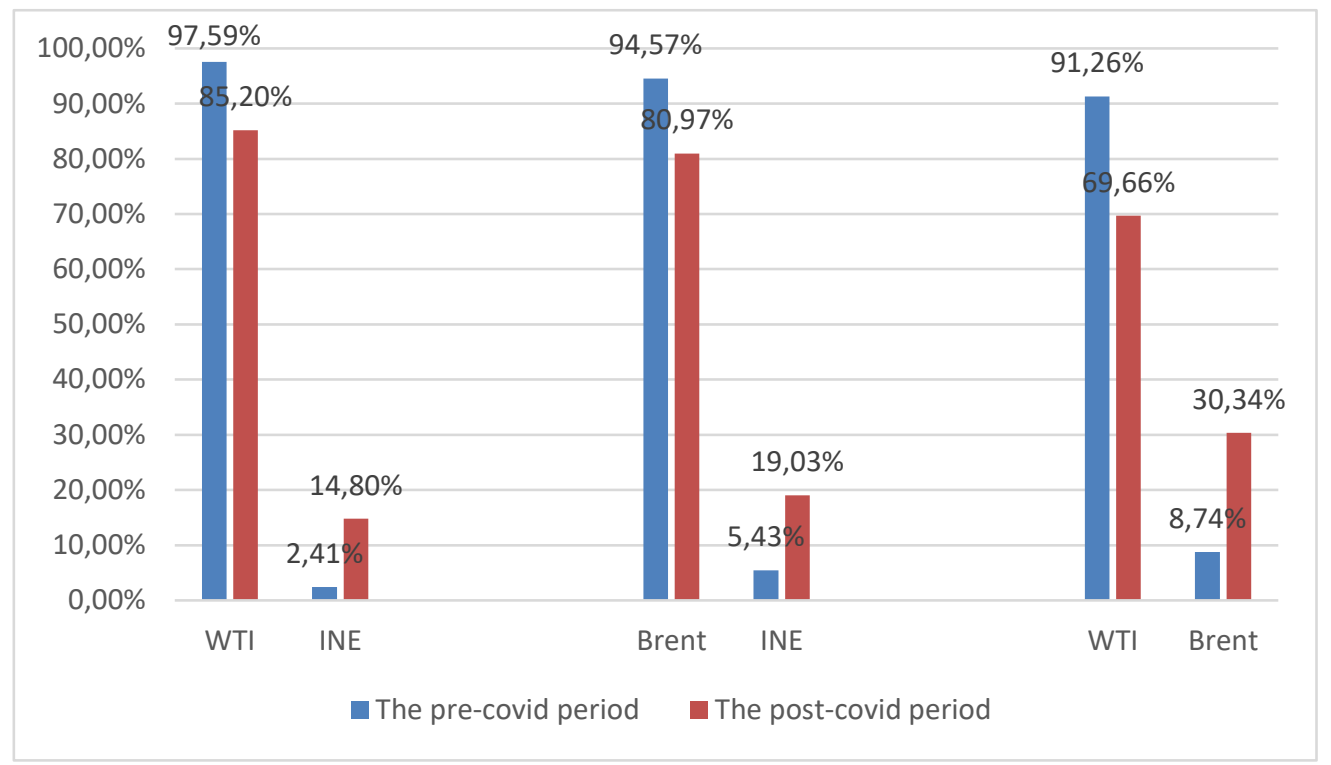

Figure 5. Comparison of CS of three markets before and after the COVID-19

\section{Conclusions}

In this paper, we provided a comprehensive empirical analysis on the price discovery of three international crude oil futures markets (WTI, Brent, INE) before and after the outbreak of the COVID-19, using various econometrics approaches. We applied both information share model and component share model to test the price discovery between these three futures markets. In our study, we took 6 March,2020 as the breakpoint based on the results of the Zivot-Andrews unit root test. Additionally, we proved the existence of cointegration relationships with structural break in May between these three international oil markets.

Employing various econometric techniques, we have an additional insight of the price discovery of international oil prices. For the whole sample we find that Brent price mainly contributes most information share in these three markets system which means Brent futures price mainly plays a leading role for WTI and INE futures price. After the breakpoint, the information advantage of Brent and WTI futures markets have decreased following the epidemic while the information share contributed by INE market has slightly increased. We induce that the increased price discovery capability of INE market is due to the Chinese government's policy to control the pandemic which gives more confidence to the crude oil futures trading market. Consequently, the Chinese oil demand increased rapidly. However, the absolute value of Brent's and WTI's information share is still larger, occupying an absolute dominant position. Additionally, in the group of Brent and WTI, WTI plays the ledlag role of Brent in the international oil market in both subperiods. We think it's a pure 
financial phenomenon that the lower price of WTI will attract more trading volume after the negative price event.

These conclusions, apart from offering a much better understanding of the price discovery of WTI, Brent, INE crude oil markets, may have important implications for helping the traders to manage risk and react rapidly in the trade of physical and financial contracts during external shocks. These findings offer practical implications for regulators, policymakers, and portfolio risk managers during the unprecedented uncertainty period provoked by the COVID-19 pandemic. They could also be useful for regulators to take different market supervision measures on traders' behavior in INE futures market because we could see that the efficiency of price discovery and price information transmission still need to be improved. It will also bring some constructive advice to help INE price to become the a potential benchmark price in Asia.

Of course, there are also some limitations in our empirical analysis. When we study the international crude oil market, we analyze each two markets of three respectively. As $\underline{\text { Yan and }}$ Zivot (2007) show, when the level of noise between two markets is different, the two typical information share measures (IS and CS) result in an overstatement of the price discovery contribution of the market with lower levels of noise. Hence, we could extend the IS and CS model into more than two markets. Another interesting subject for future research is the price relationship between crude oil futures markets and many other financial markets such as stock, currency and so on. Taking the world financial system and exogenous shocks into account will help us to know the internal logic of crude oil price formation. Therefore, during the process of the price discovery, more factors can be taken into consideration to make the research more comprehensive and objective.

\section{Reference}

Abuzayed, B., Bouri, E., Al-Fayoumi, N., \& Jalkh, N. (2021). Systemic risk spillover across global and country stock markets during the COVID-19 pandemic. Economic Analysis and Policy, 71, 180-197. doi:https://doi.org/10.1016/j.eap.2021.04.010

Aggarwal, N., \& Thomas, S. (2019). When stock futures dominate price discovery. Journal of Futures Markets, 39(3), 263-278. doi:https://doi.org/10.1002/fut.21973

Alexakis, C., Eleftheriou, K., \& Patsoulis, P. (2021). COVID-19 containment measures and stock market returns: An international spatial econometrics investigation. J Behav Exp Finance, 29, 100428. doi:10.1016/j.jbef.2020.100428

Alqahtani, A., Selmi, R., \& Hongbing, O. (2021). The financial impacts of jump processes in the crude oil price: Evidence from G20 countries in the pre- and post-COVID-19. Resources Policy, 72, 102075. doi:https://doi.org/10.1016/j.resourpol.2021.102075

Ashraf, B. N. (2020). Economic impact of government interventions during the COVID-19 pandemic: International evidence from financial markets. J Behav Exp Finance, 27, 100371. doi:https://doi.org/10.1016/j.jbef.2020.100371 
Baillie, R., Booth, G., Tse, Y., \& Zabotina, T. (2002). Price Discovery and Common Factor Models. Journal of Financial Markets, 5, 309-321. doi:10.1016/S13864181(02)00027-7

Bakas, D., \& Triantafyllou, A. (2020). Commodity price volatility and the economic uncertainty of pandemics. Economics Letters, 193, 109283. doi:https://doi.org/10.1016/j.econlet.2020.109283

Ben Amar, A., Fateh, B., Youssef, A. B., Chiao, B., \& Guesmi, K. (2021). The unprecedented reaction of equity and commodity markets to COVID-19. Finance Research Letters, 38(C), S1544612320316676.

Bentzen, J. (2007). Does OPEC influence crude oil prices? Testing for co-movements and causality between regional crude oil prices. Applied Economics, 39(11), 1375-1385. doi:10.1080/00036840600606344

Booth, G. G., So, R. W., \& Tse, Y. (1999). Price discovery in the German equity index derivatives markets. Journal of Futures Markets, 19(6), 619-643. doi:https://doi.org/10.1002/(SICI)1096-9934(199909)19:6<619::AIDFUT1>3.0.CO;2-M

Bourghelle, D., Jawadi, F., \& Rozin, P. (2021). Oil price volatility in the context of Covid-19. International Economics, 167, 39-49. doi:https://doi.org/10.1016/j.inteco.2021.05.001

Chu, Q. C., Hsieh, W.-l. G., \& Tse, Y. (1999). Price discovery on the S\&P 500 index markets: An analysis of spot index, index futures, and SPDRs. International Review of Financial Analysis, 8(1), 21-34. doi:https://doi.org/10.1016/S1057-5219(99)00003-4

de Jong, F. (2002). Measures of contributions to price discovery: a comparison. Journal of Financial Markets, 5(3), 323-327.

Elder, J., Miao, H., \& Ramchander, S. (2014). Price discovery in crude oil futures. Energy Economics, 46, S18-S27. doi:https://doi.org/10.1016/j.eneco.2014.09.012

Engle, R. F., \& Granger, C. W. J. (1987). Co-Integration and Error Correction: Representation, Estimation, and Testing. Econometrica, 55(2), 251-276. doi: $10.2307 / 1913236$

Garbade, K. D., \& Silber, W. L. (1983). Price Movements and Price Discovery in Futures and Cash Markets. The Review of Economics and Statistics, 65(2), 289-297. doi:10.2307/1924495

Gonzalo, J., \& Granger, C. (1995). Estimation of Common Long-Memory Components in Cointegrated Systems. Journal of Business \& Economic Statistics, 13(1), 27-35. doi: $10.2307 / 1392518$

Gregory, A., \& Hansen, B. (1996). Residual-based tests for cointegration in models with regime shifts. Journal of Econometrics, 70(1), 99-126.

Hammoudeh, S., Ewing, B., \& Thompson, M. A. (2008). Threshold Cointegration Analysis of Crude Oil Benchmarks. The Energy Journal, Volume 29(Number 4), 79-96.

Harris, F., McInish, T., \& Wood, R. (2009). The Need for a Unified Approach to Price Discovery: CFS and IS Metrics Before and After Reg NMS. SSRN Electronic Journal. doi:10.2139/ssrn.1107527

Hasbrouck, J. (1995). One Security, Many Markets: Determining the Contributions to Price Discovery. The Journal of Finance, 50(4), 1175-1199. doi:https://doi.org/10.1111/j.1540-6261.1995.tb04054.x 
Irwin, H. S. (1933). [Future Trading Upon Organized Commodity Markets in the United States, G. Wright Hoffman]. Journal of Political Economy, 41(2), 257-260.

Lehmann, B. N. (2002). Some desiderata for the measurement of price discovery across markets. Journal of Financial Markets, 5(3), 259-276.

Nippani *, S., \& Washer, K. M. (2004). SARS: a non-event for affected countries' stock markets? Applied Financial Economics, 14(15), 1105-1110. doi:10.1080/0960310042000310579

Palao, F., Pardo, Á., \& Roig, M. (2020). Is the leadership of the Brent-WTI threatened by China's new crude oil futures market? Journal of Asian Economics, 70, 101237. doi:https://doi.org/10.1016/j.asieco.2020.101237

Perron, P. (1989). The Great Crash, the Oil Price Shock, and the Unit Root Hypothesis. Econometrica, 57(6), 1361-1401. doi:10.2307/1913712

Phillips, P. C. B. (1987). Time Series Regression with a Unit Root. Econometrica, 55(2), $277-$ 301. doi:10.2307/1913237

Schwarz, T. V., \& Szakmary, A. C. (1994). Price discovery in petroleum markets: Arbitrage, cointegration, and the time interval of analysis. Journal of Futures Markets, 14(2), 147-167. doi:https://doi.org/10.1002/fut.3990140204

Shao, Y.-H., Yang, Y.-H., Shao, H.-L., \& Stanley, H. E. (2019). Time-varying lead-lag structure between the crude oil spot and futures markets. Physica A: Statistical Mechanics and its Applications, 523, 723-733. doi:https://doi.org/10.1016/j.physa.2019.03.002

Silvério, R., \& Szklo, A. (2012). The effect of the financial sector on the evolution of oil prices: Analysis of the contribution of the futures market to the price discovery process in the WTI spot market. Energy Economics, 34(6), 1799-1808. doi:https://doi.org/10.1016/j.eneco.2012.07.014

Wang, L., \& Kutan, A. (2013). The Impact of Natural Disasters on Stock Markets: Evidence from Japan and the US. Comparative Economic Studies, 55(4), 672-686.

Wang, Y., \& Wu, C. (2013). Are crude oil spot and futures prices cointegrated? Not always! Economic Modelling, 33, 641-650. doi:https://doi.org/10.1016/j.econmod.2013.05.013

Wlazlowski, S., Hagstromer, B., \& Giulietti, M. (2011). Causality in crude oil prices. Applied Economics, 43, 3337-3347. doi:10.1080/00036841003636250

Yan, B., \& Zivot, E. (2007). A structural analysis of price discovery measures. Journal of Financial Markets, 13, 1-19. doi:10.1016/j.finmar.2009.09.003

Yang, J., \& Zhou, Y. (2020). Return and volatility transmission between China's and international crude oil futures markets: A first look. Journal of Futures Markets, 40(6), 860-884. doi:https://doi.org/10.1002/fut.22103

Zaremba, A., Aharon, D. Y., Demir, E., Kizys, R., \& Zawadka, D. (2021). COVID-19, government policy responses, and stock market liquidity around the world: A note. Research in international business and finance, 56, 101359-101359. doi:10.1016/j.ribaf.2020.101359

Zivot, E., \& Donald, W. K. A. (1992). Further Evidence on the Great Crash, the Oil-Price Shock, and the Unit-Root Hypothesis. Journal of Business \& Economic Statistics, 10(3), 251-270. doi:10.2307/1391541 



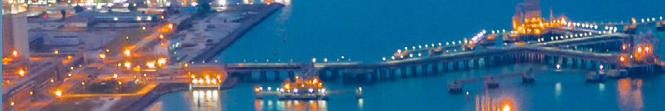

2. S-

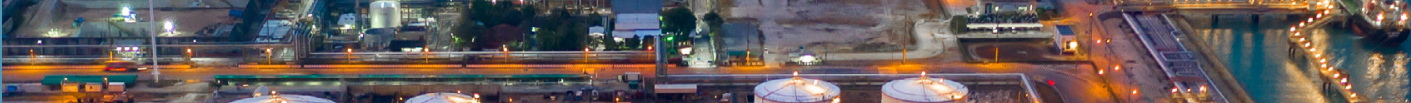

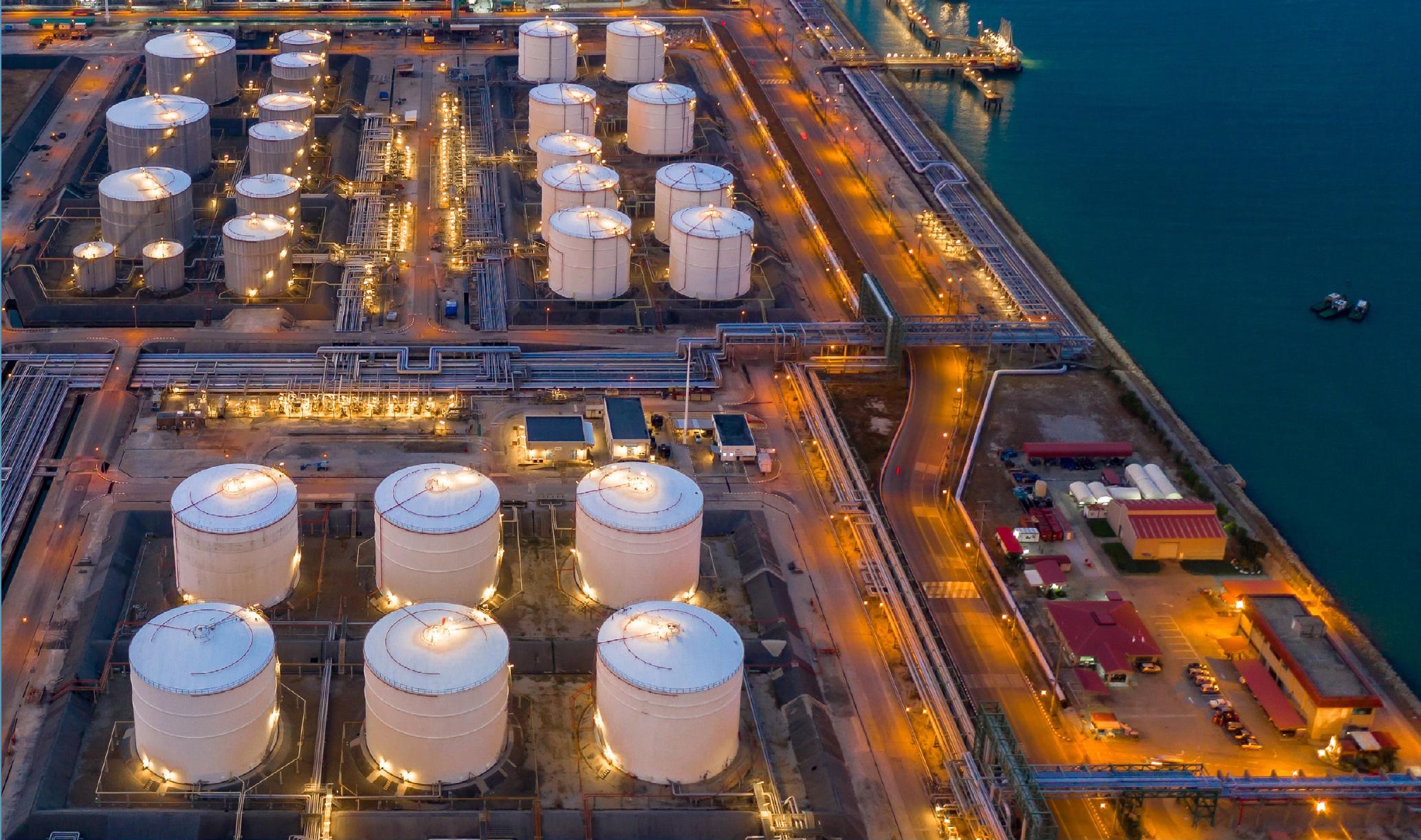

Retrouvez toute la collection

https://www.ifpenergiesnouvelles.fr/article/les-cahiers-leconomie

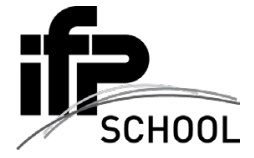

228 - 232 avenue Napoléon Bonaparte

92852 Rueil-Malmaison

www.ifpschool.com

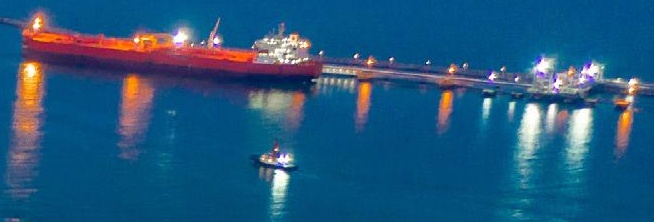

